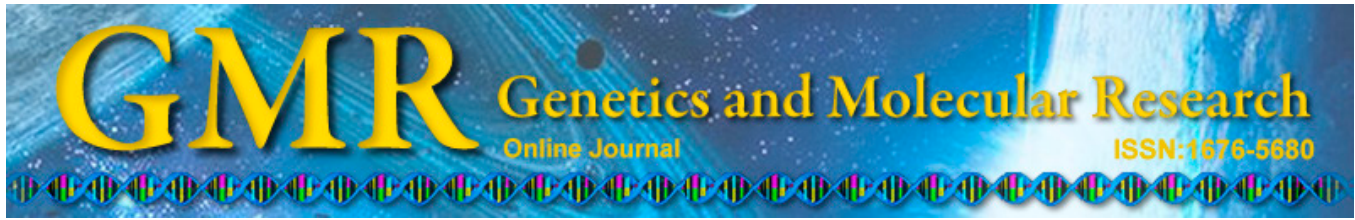

\title{
Health and production traits in bovine are associated with single nucleotide polymorphisms in the NOD2 gene
}

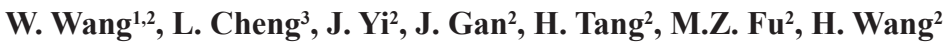 \\ and S.J. Lai ${ }^{1}$ \\ ${ }^{1}$ College of Animal Science and Technology, Sichuan Agricultural University, \\ Ya'an, Sichuan, China \\ ${ }^{2}$ Sichuan Animal Science Academy, Chengdu, Sichuan, China \\ ${ }^{3}$ Sichuan Animal Husbandry Station, Chengdu, Sichuan, China \\ Corresponding author: S.J. Lai \\ E-mail: 1sj5791@263.net
}

Genet. Mol. Res. 14 (2): 3570-3578 (2015)

Received May 30, 2014

Accepted October 22, 2014

Published April 17, 2015

DOI http://dx.doi.org/10.4238/2015.April.17.6

\begin{abstract}
The NOD2 gene plays a fundamental role in initiating the inflammatory and subsequent immune response. NOD2 was previously identified as a susceptibility locus for inflammatory bowel diseases in humans. In this study, we detected 2 mutations in exon 12 $(\mathrm{A} \rightarrow \mathrm{T}, \mathrm{G} \rightarrow \mathrm{A})$ among 5 cattle breeds $(\mathrm{N}=315)$ and analyzed their associations with production traits and genetic resistance against bovine mastitis in Chinese Holstein and Chinese Simmental breeds (N =218). The transitions $(\mathrm{A} \rightarrow \mathrm{T})$ at position $114 \mathrm{bp}$ were associated with somatic cell score $(\mathrm{P}<0.01)$. The $\mathrm{G} \rightarrow \mathrm{A}$ at position 1594 bp plays a critical role in increasing 305-day milk yields. In Chinese Holstein and Chinese Simmental breeds, the BB genotype may contribute to disease susceptibility. Compared to all genotypic combinations, the A, B, and
\end{abstract}


FF genotypes are beneficial not only for reducing somatic cell score but also for increasing production.

Key words: Bovine mastitis; NOD2 gene; Somatic cell score

\section{INTRODUCTION}

Inflammatory diseases such as bovine mastitis, is one of the main causes of the losses in the dairy industry, either clinical, or subclinical. Economic consequences include decreased milk production, alteration of cheese-making properties, and increased production costs (Pellegrini, 1994). Bovine mastitis is usually due to a microbial infection (Watts, 1988). The bacteria responsible for bovine mastitis can be classified as environmental (Escherichia coli, Streptococcus dysgalactiae, Streptococcus parauberis, and Streptococcus uberis) or contagious (Staphylococcus aureus and Streptococcus agalactiae) (Bramley, 1996). The predisposition of mastitis has been proposed to be genetically determined in epidemiological studies with average heritability of 0.04 (Nash et al., 2004; Mark et al., 2005). However, the relative candidate genes involved in this process are unknown.

The innate immune response represents the first defense line for preventing systemic infection with bacteria. Nod2 is a key component in the innate immune system, and may be involved in the innate immune response to peptidoglycans (Bonen et al., 2003) and detection of bacterial products to induce the activation of proinflammatory signaling pathways, such as the nuclear factor- $\kappa B$ pathway (Girardin et al., 2001; Inohara et al., 2001). Lipopolysaccharides, as the main endotoxins derived from Gram-positive and Gram-negative bacteria, have been suggested to play a pivotal role in the pathogenesis of a variety of infectious and allergic diseases (Hugot et al., 2001). The NOD2 gene, located on chromosome 16q21, has 12 exons and encodes a protein of 1040 amino acids (Ogura et al., 2001). The Nod2 protein contains a carboxy (C)-terminal leucine rich repeat domain, a nucleotide-binding site domain, and 2 amino (N)-terminal domains (CARDs) (Girardin et al., 2002; Inohara et al., 2002). The leucine rich repeat domain is involved primarily in the recognition of bacterial peptidoglycans, and the CARD domains are known to interact with CARD containing serine/threonine kinase Rip2 via homophilic CARD-CARD interactions; this leads to the activation of nuclear factor$\kappa \mathrm{B}$ (Ogura et al., 2001). The NOD2 gene has been widely adopted in studies of the human immune system (Uehara et al., 2002) and swine immune system (Shimosato et al., 2005a,b; Tohno et al., 2008). Recently, the NOD2 gene was detected in bovine mammary glands following intramammary infection with $S$. aureus (Cormac et al., 2011). However, the association between mutations in genetic polymorphism of NOD2 gene and genetic resistance against bovine mastitis has not been examined.

The objective of this study was to identify the single-nucleotide polymorphisms in 8 , 11 , and 12 exons of the NOD2 gene in 5 cattle breeds and to analyze the relationship between gene variation and bovine mastitis, 305-day milk yields, and constituents of milk, which will be beneficial for cattle breeding and genetics.

\section{MATERIAL AND METHODS}

\section{Animal source}

Tissue and milk samples from 218 cattle were randomly obtained from 2 breeds 
(Chinese Holstein and Chinese Simmental). To obtain more information on the genetic structure of NOD2 among different cattle populations, 86 cattle were randomly sampled from 3 Chinese indigenous breeds (Dechang buffalo, Tongjiang cattle, and Maiwa yak). All experimental procedures were approved by the Institutional Animal Care and Use Committee of Sichuan Provincial Key Laboratory of Animal Breeding and Genetics, Sichuan Animal Science Academy.

\section{Milk sampling and analysis}

Quarter milk samples were collected aseptically by dairy personnel according to International Dairy Federation standards (IDF, 1985). Milk samples were examined for fat, lactose, and total protein contents. The milk samples were screened for their somatic cell count (SCC) according to the National Mastitis Council (NMC, 2004). Milk SCC data were normalized by logarithmic transformation into somatic cell score (SCS) as SCS $=\log$ base $2(\mathrm{SCC} / 100)+3$, where SCC is cells $/ \mu \mathrm{L}$ (Schukken et al., 2003).

\section{DNA isolation and mutation screening}

Genomic DNA was isolated from ear tissue and stored at $-80^{\circ} \mathrm{C}$ following standard procedures (Hirschhorn et al., 2002). Eight primer pairs (Table 1) were designed to amplify 3 exons of the cattle NOD2 gene according to published gene sequences (GenBank accession numbers: AY518755, AY518758, AY518759). Polymerase chain reaction (PCR) was performed in a $25 \mu \mathrm{L}$ volume containing $4 \mu \mathrm{L}$ DNA template $(20 \mathrm{ng} / \mu \mathrm{L}), 25 \mu \mathrm{L} 2 \mathrm{X}$ Taq PCR MasterMix (TIANGEN, Beijing, China), $1.5 \mu \mathrm{L}$ of each primer $(10 \mu \mathrm{M})$, and $18 \mu \mathrm{L} \mathrm{ddH}_{2} \mathrm{O}$. The PCR protocol for the $N O D 2$ gene was 5 min at $95^{\circ} \mathrm{C}, 35$ cycles of $94^{\circ} \mathrm{C}$ for $30 \mathrm{~s}, 46-54^{\circ} \mathrm{C}$ annealing for $30 \mathrm{~s}, 72^{\circ} \mathrm{C}$ for $40 \mathrm{~s}$, and a final extension at $72^{\circ} \mathrm{C}$ for $10 \mathrm{~min}$. For the singlestrand conformation polymorphism, $1.5 \mu \mathrm{L}$ PCR products was added to $6 \mu \mathrm{L}$ loading buffer (20 mM EDTA, $0.025 \%$ bromophenol blue, and $0.025 \%$ xylenecyanol FF) denatured at $98^{\circ} \mathrm{C}$ for $10 \mathrm{~min}$, and placed on ice for $10 \mathrm{~min}$. The denatured PCR products were analyzed on a $10 \%$ polyacrylamide gel in $1 \mathrm{X}$ Tris/borate/EDTA buffer and electrophoresed at constant voltage $(8 \mathrm{~V} / \mathrm{cm})$ for $12-14 \mathrm{~h}$. DNA bands on the gel were detected by silver staining.

\begin{tabular}{|c|c|c|c|}
\hline Primers & Primer sequence $\left(5^{\prime}-3^{\prime}\right)$ & Position (bp) & Annealing temperature $\left({ }^{\circ} \mathrm{C}\right)$ \\
\hline \multirow{2}{*}{ Seq 1} & F: 5'-CTCTTTGCTTTATCCCTTTC-3' & 42 & 53.2 \\
\hline & R: 5'-GATGTGCTTTCCTGTGCC-3' & 296 & \\
\hline \multirow[t]{2}{*}{ Seq 2} & F: 5'-AAAGCACATCAGTGCCTTGT-3' & 287 & 53.7 \\
\hline & R: 5'-TACTTCCCGAGCATCCCT-3' & 506 & \\
\hline \multirow[t]{2}{*}{ Seq 3} & F: 5'-ATGGATGCCACTGAGTATTT-3' & 446 & 51.8 \\
\hline & R: 5'-CAGGGTACAAGGGAAAGAT-3' & 649 & \\
\hline \multirow[t]{2}{*}{ Seq 4} & F: 5'-GGCATTCTCACCTTTGAT-3' & 615 & 50.7 \\
\hline & R: 5'-TTTGGATACGGAGTTGTT-3' & 893 & \\
\hline \multirow[t]{2}{*}{ Seq 5} & F: 5'-CTCAGTGTCCCAGCAGAA-3' & 1538 & 52 \\
\hline & R: 5'-ATCCACCTTGATGAGCAG-3' & 1747 & \\
\hline \multirow[t]{2}{*}{ Seq 6} & F: 5'-ATTAGCAAGGACTCAGGT-3' & 1789 & 46.6 \\
\hline & R: 5'-ATGTATAGCACAAGGAAC-3' & 2003 & \\
\hline \multirow[t]{2}{*}{ Seq 7} & F: 5'-CACTTTGCTGGGACCTGA-3' & 63 & 56 \\
\hline & R: 5'-AACTGCGGGACGAACACT-3' & 319 & \\
\hline \multirow[t]{2}{*}{ Seq 8} & F: 5'-ATCTGGTGAATGGAGGAG-3' & 90 & 50.1 \\
\hline & R: 5'-CTAGGGAGCTGATGTGGT-3' & 307 & \\
\hline
\end{tabular}




\section{Sequencing of polymorphism fragment}

PCR products were purified using spin columns (Watson BioTechnologies, Shanghai, China) and sequenced in both directions using the BigDye Terminator sequencing kit (Applied Biosystems, Foster City, CA, USA). Sequencing was performed in a 3700 DNA sequencer (Applied Biosystems) according to manufacturer instructions.

\section{Statistical analysis}

Gene frequencies were determined for each breed by direct counting. v2 tests were used to determine whether the individual variant was in Hardy-Weinberg equilibrium. The genotype and allele frequency distributions were compared using the Chi square test. The traits were compared between genotypes. The relationship between genotypes of the NOD2 gene and bovine mastitis and milk quality were analyzed using one-way analysis (Wang et al., 2010; Ren et al., 2009) with the following model:

$$
\mathrm{Y}_{\mathrm{ijkl}}=\mu+\mathrm{A}_{\mathrm{i}}+\mathrm{B}_{\mathrm{j}}+\mathrm{S}_{\mathrm{k}}+\mathrm{G}_{1}+\mathrm{E}_{\mathrm{ijk} \mathrm{l}}
$$

(Equation)

$Y i j k l=$ observed value; $\mu=$ overall mean for each trait; $B F i=$ fixed effect of $i^{\text {th }}$ breed and farm; $M j=$ fixed effect of $j^{\text {th }}$ month of slaughtering; $G=$ fixed effect of $\mathrm{k}^{\text {th }}$ single SNP marker genotype; Eijkl = random error.

\section{RESULTS AND DISCUSSION}

\section{Mutational analysis of the cattle NOD2 gene}

Investigation of 3 coding exons of the NOD2 gene revealed 2 mutations in exon 12. The 2 transitions, $A \rightarrow T$ at position 114 base pairs and $\mathrm{G} \rightarrow \mathrm{A}$ at position 1594 base pairs were non-synonymous substitutions (Figure 1). Six genotypes, including AA, AB, BB, EE, $\mathrm{EF}$, and $\mathrm{EF}$, were determined by 4 alleles, $\mathrm{A}, \mathrm{B}, \mathrm{E}$, and $\mathrm{F}$, which were observed in exon 12 within the 5 breeds (Figure 2). The $\chi^{2}$-test showed that the genotype distributions of AA, $\mathrm{AB}$, and $\mathrm{BB}$ in Chinese Holstein, Chinese Simmental, Tongjiang cattle, and Maiwa yak were not in Hardy-Weinberg equilibrium $(\mathrm{P}<0.05)$, while for the Dechang buffalo, the null hypothesis was not rejected $(\mathrm{P}>0.05)$; the genotype distributions of $\mathrm{EE}, \mathrm{EF}$, and $\mathrm{FF}$ in Chinese Simmental, Dechang buffalo, and Maiwa yak were not in Hardy-Weinberg equilibrium $(\mathrm{P}<0.05)$, while Chinese Holstein and Tongjiang cattle were in Hardy-Weinberg equilibrium $(\mathrm{P}<0.05)$ (Table 2$)$.

In all population, alleles $\mathrm{A}(0.6459)$ and $\mathrm{E}(0.6590)$ were more frequent than alleles $\mathrm{B}(0.3541)$ and $\mathrm{F}$ (0.3410), indicating that alleles A and $\mathrm{E}$ were advantage alleles (Table 2). Among the 87 cattle randomly sampled from 3 Chinese indigenous breeds, genotypes BB and FF were not detected, while the average frequencies of genotypes $\mathrm{AA}, \mathrm{AB}, \mathrm{EE}$, and $\mathrm{EF}$ were 
$0.4253,0.5747,0.4483$, and 0.5517 , which were not significantly different from that in Chinese Holstein and Chinese Simmental breeds $(0.4128,0.4128,0.3945$, and 0.4771) (Table 2). Several studies reported that individuals of Dechang buffalo, Tongjiang cattle, and Maiwa yak were not predisposed to mastitis (Chu, 1999; Tohno et al., 2008). This phenomenon revealed that alleles $\mathrm{B}$ and $\mathrm{F}$ might increase the chance of mastitis infection.

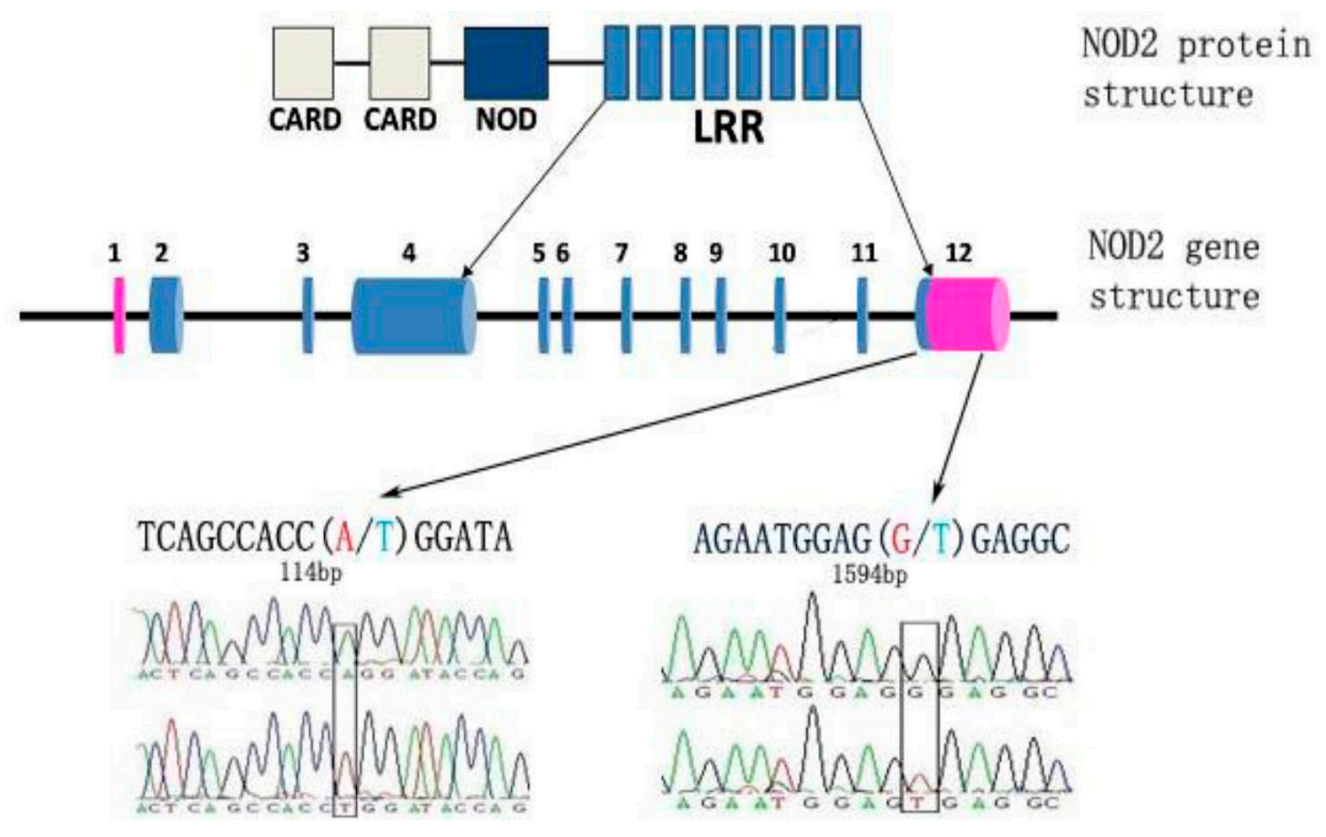

Figure 1. NOD2 structure and location of single nucleotide polymorphisms.

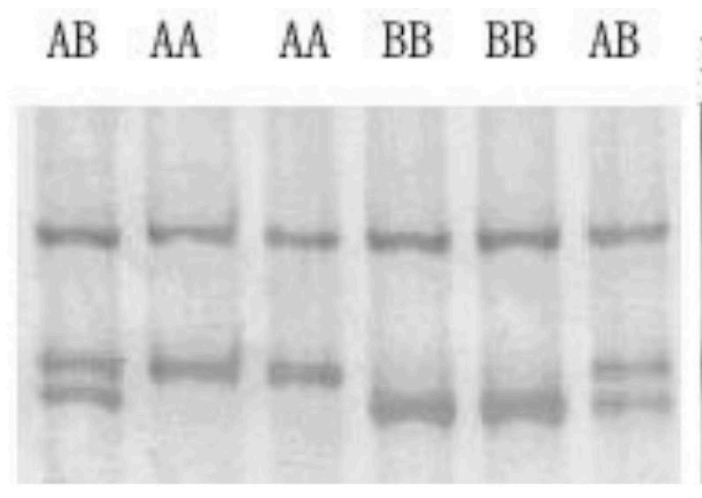

(a)

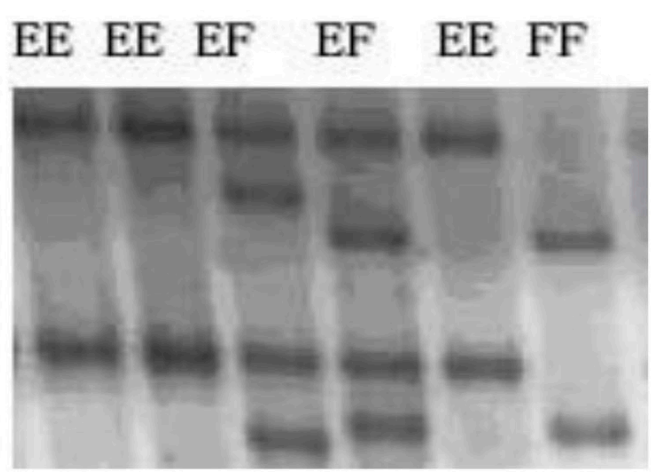

(b)

Figure 2. Polymorphisms in exon 12 of NOD2 gene. a) Electrophoresis of PCR-SSCP, AA, BB, and AB. b) Electrophoresis of PCR-SSCP, EE, FF, and EF. 


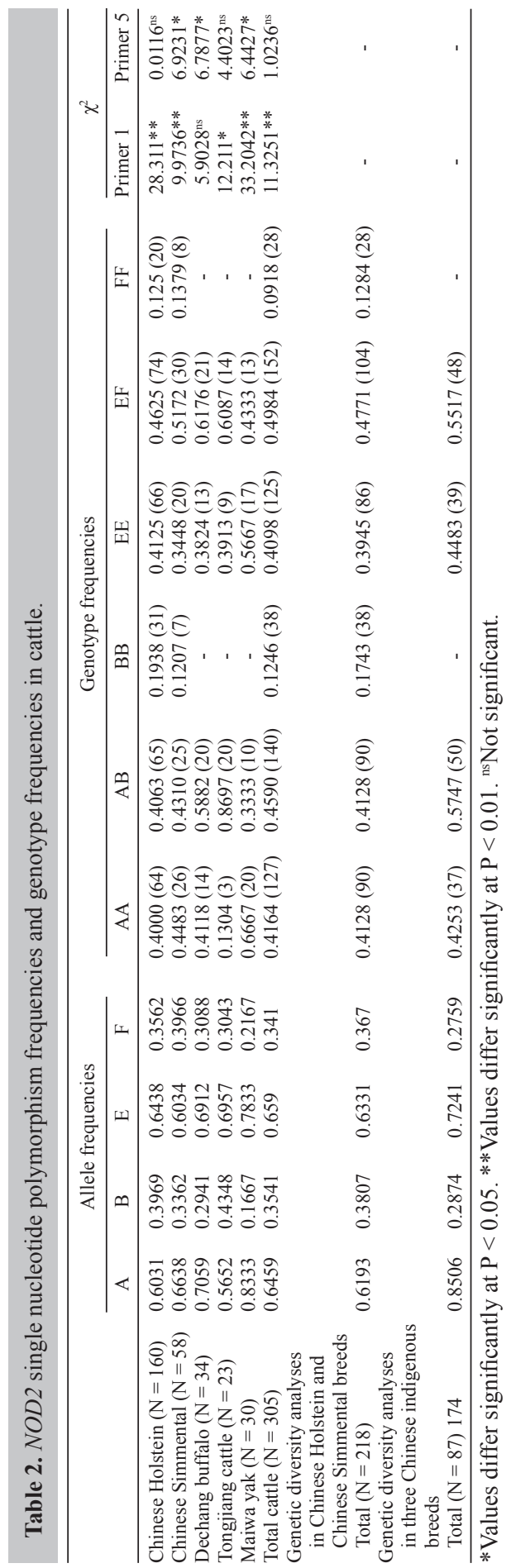




\section{Association between NOD2 and mastitis in cattle}

Statistical analyses revealed associations between transitions $\mathrm{A} \rightarrow \mathrm{T}$ and $\mathrm{G} \rightarrow \mathrm{A}$ and SCS. The generalized linear model was found to be useful, and the transitions $\mathrm{A} \rightarrow \mathrm{T}$ showed a significant association with SCS $(\mathrm{P}<0.01)$ (Table 3$)$. This transition has been described to play a critical role in increasing SCS in Canadian Holsteins (Sameer et al., 2007). Among the 218 individuals of Chinese Holstein and Chinese Simmental breeds groups, the animals with genotype BB had significantly higher SCS compared with genotypes $\mathrm{AA}$ and $\mathrm{AB}(\mathrm{P}<0.01)$ (Table 3$)$. The genotypic combination $\mathrm{BBFF}$ had a higher SCS than AAFF and ABFF $(\mathrm{P}<0.05)$ and was significantly higher than other genotypic combinations $(\mathrm{P}<0.01)$ (Table 4$)$. This indicates that the BB genotype may contribute to disease susceptibility; therefore, the NOD2 gene may affect SCS. The association between the NOD2 gene with protein, fat, and 305-day milk yields in Chinese Holstein and Chinese Simmental breeds groups $(\mathrm{N}=218)$ were analyzed (Table 3$)$. The allele F harboring the mutation $\mathrm{G} \rightarrow \mathrm{A}$ also contributed to the high protein and 305-day milk yields. The genotypic combination BBFF and AAFF showed higher protein and 305-day milk yields, respectively, compared to other genotypic combinations. Interestingly, the genotypic combinations simultaneously carrying allele A, B, and genotype FF were beneficial not only for reducing SCS, but also for increasing production. Thus, selection for these genotypic combinations in the population appears to be promising.

In summary, we detected significant associations between NOD2 polymorphisms and the incidence of mastitis, protein, and 305-day milk yields. Allele B increased SCS, while allele $\mathrm{F}$ increased protein and 305-day milk yields in cattle.

\footnotetext{
Table 3. Healthy and production performance comparison of individuals with different genotypes and effects (P value) of polymorphism of NOD2.

\begin{tabular}{|c|c|c|c|c|c|c|c|c|}
\hline \multicolumn{7}{|c|}{ Genotypes } & \multicolumn{2}{|c|}{ P Value } \\
\hline & AA & $\mathrm{AB}$ & BB & $\mathrm{EE}$ & $\mathrm{EF}$ & $\mathrm{FF}$ & Primer1 & Primer2 \\
\hline SCS & $3.9661 \pm 0.1816^{\mathrm{A}}$ & $3.7663 \pm 0.1789^{A}$ & $4.98 \pm 0.2612^{\mathrm{B}}$ & $3.9927 \pm 0.1801$ & $3.8927 \pm 0.1640$ & $4.1465 \pm 0.2902$ & $<0.0001^{* *}$ & $0.7159^{\mathrm{ns}}$ \\
\hline Fat yield (\%) & $3.3146 \pm 0.1318^{\mathrm{a}}$ & $3.4771 \pm 0.1298^{\mathrm{a}}$ & $2.6335 \pm 0.1896^{\mathrm{b}}$ & $3.1975 \pm 0.1307$ & $3.3511 \pm 0.1190$ & $2.9372 \pm 0.2106$ & & \\
\hline $\begin{array}{l}\text { Protein } \\
\text { yield }(\%)\end{array}$ & $3.2530 \pm 0.3795^{\mathrm{A}}$ & $3.1886 \pm 0.3737^{\mathrm{A}}$ & $4.3422 \pm 0.5458^{\mathrm{B}}$ & $3.3991 \pm 0.3394^{\mathrm{A}}$ & $3.269 \pm 0.3213^{A}$ & $4.0166 \pm 0.4585^{\mathrm{B}}$ & & \\
\hline $\begin{array}{l}\text { 305-day } 658 \\
\text { milk yields }\end{array}$ & $582.2805 \pm 153.2662^{\mathrm{a}}$ & $6631.3063 \pm 150.4436^{\mathrm{a}}$ & $7102.0215 \pm 224.4428^{\mathrm{b}}$ & $6330.955 \pm 149.2562^{\mathrm{A}}$ & $6777.5437 \pm 154.3373^{\mathrm{a}}$ & $7461.012 \pm 231.0142^{\mathrm{Bb}}$ & & \\
\hline
\end{tabular}

Values with different superscripts within the same line differ significantly at $\mathrm{P}<0.01(\mathrm{~A}, \mathrm{~B})$ and $\mathrm{P}<0.05(\mathrm{a}, \mathrm{b})$, SE standard error.
}

\section{ACKNOWLEDGMENTS}

Research partially supported by the Open Fund of Sichuan Provincial Key Laboratory of Animal Breeding and Genetics, the Sichuan Animal Science Academy, and the National 11th Five-Year Technology based Plan Topic (\#2006BAD04A17). 


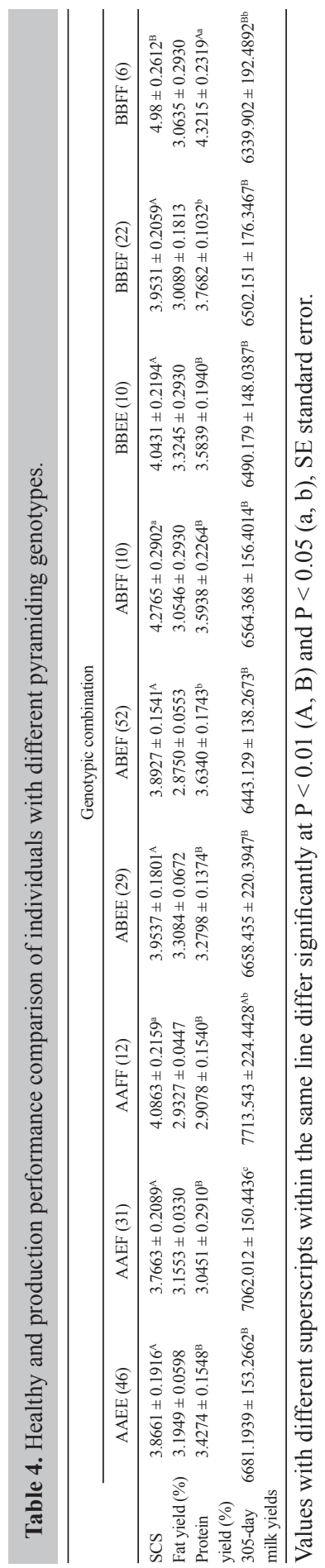




\section{REFERENCES}

Bonen DK, Ogura Y, Nicolae DL, Inohara N, et al. (2003). Crohn's disease-associated NOD2 variants share a signaling defect in response to lipopolysaccharide and peptidoglycan. Gastroenterology 124: 140-147.

Bramley AJ (1996). Current concepts of bovine mastitis. National Mastitis Council, Madison, WI.

Chu MX (1999). The harm, occurrence regularity and preventive treatment of bovine mastitis. Chin. Cattle. (4): 39-40.

Cormac J, Whelehan, KG Meade KG, Eckersall PD, et al. (2011). Experimental Staphylococcus aureus infection of the mammary gland induces region-specific changes in innate immune gene expression. Vet. Immunol. Immunopathol. 140: 181-189.

Girardin SE, Tournebize R, Mavris M, Page AL, et al. (2001). CARD4/Nod1 mediates NF-kappaB and JNK activation by invasive Shigella flexneri. EMBO Rep. 2: 736-742.

Girardin SE, Sansonetti PJ and Philpott DJ (2002). Intracellular vs extracellular recognition of pathogens-common concepts in mammals and flies. Trends Microbiol. 10: 193-199.

Hugot JP, Chamaillard M, Zouali H, Lesage S, et al. (2001). Association of NOD2 leucine-rich repeat variants with susceptibility to Chron's disease. Nature 411: 599-603.

Inohara N, Ogura Y, Chen FF, Muto A, et al. (2001). Human Nod1 confers responsiveness to bacterial lipopolysaccharides. J. Biol. Chem. 276: 2551-255.

Inohara N, Ogura Y and Nuñez G (2002). Nods: a family of cytosolic proteins that regulate the host response to pathogens. Curr. Opin. Microbiol. 5: 76-80.

International Dairy Federation (1985). Laboratory methods for use in mastitis work. International Dairy Federation, Brussels, Belgium.

Mark T, Fikse WF, Emanuelson U and Philipsson J (2005). International Genetic Evaluations of Holstein sires for milk somatic cell and clinical mastitis. J. Dairy Sci. 85: 2384-2392.

Nash DL, Rogers GW, Cooper JB, Hargrove GL, et al. (2004). Heritability of clinical mastitis incidence and relationships with sire transmitting abilities for somatic cell score, udder type traits, productive life, and protein yield. J. Dairy Sci. 83: 2350-2360.

National Mastitis Council. Microbiological (2004). Procedures for the Diagnosis of Bovine Udder Infection and Determination of Milk Quality, 4th edn. National Mastitis Council, W. D. Hoard and Sons Co., Fort Atkinson, WI.

Ogura Y, Inohara N, Benito A, Chen FF, et al. (2001). Nod2, a Nod1/Apaf-1 family member that is restricted to monocytes and activates NF-kappaB. J. Biol. Chem. 276: 4812-4818.

Pellegrini O, Aurel MR, Lagriffoul G, Marie C, et al. (1994). Relations entre les comptages de cellules somatiques, les caractéristiques physico-chimiques et l'aptitude à la coagulation par la présure delaits individuels de brebis de race Lacaune. In: Proceedings of the International Symposiumon Somatic Cells and Milk of Small Ruminants, Bella, September 25-27, 1994. Italy, EAAP Publication No. 77, 253-258.

Ren G, Chen H, Zhang LZ, Lan XY, et al. (2009). A coding SNP of LHX4 gene is associated with body weight and body length in bovine. Mol. Biol. Rep. 37: 417-422.

Shimosato T, Kitazawa H, Katoh S, Tohno M, et al. (2005a). Augmentation of T(H)-1 type response by immunoactive AT oligonucleotide from lactic acid bacteria via Toll-like receptor 9 signaling. Biochem. Biophys. Res. Commun. 326: $782-787$.

Shimosato T, Tohno M, Kitazawa H, Katoh S, et al. (2005b). Toll-like receptor 9 is expressed on follicle-associated epithelia containing M cells in swine Peyer's patches. Immunol. Lett. 98: 83-89.

Tohno M, Ueda W, Azuma Y, Shimazu T, et al. (2008). Molecular cloning and functional characterization of porcine nucleotide-binding oligomerization domain-2 (NOD2). Mol. Immunol. 45: 194-203.

Uehara A, Sugawara S and Takada H (2002). Priming of human oral epithelial cells by interferon-gamma to secrete cytokines in response to lipopolysaccharides, lipoteichoic acids and peptidoglycans. J. Med. Microbiol. 51: 626-634.

Watts JL (1988). Etiological agents of bovine mastitis. Vet. Microbiol. 16: 41-66.

Wang J, Li ZJ, Lan XY, Hua LS, et al. (2010). Two novel SNPs in the coding region of the bovine PRDM16 gene and its associations with growth traits. Mol. Biol. Rep. 37: 571-577. 